\title{
Dispersal of females and differentiation between populations of Epirrita autumnata (Lepidoptera: Geometridae) inferred from variation in mitochondrial DNA
}

\author{
NIINA SNÄLL ${ }^{1,2}$, KIRSI HUOPONEN $^{3}$, IRMA SALONIEMI ${ }^{2}$, MARJA-LiISA SAVONTAUS ${ }^{1}$ and KaI RUOHOMÄKI ${ }^{2}$ \\ ${ }^{1}$ Laboratory of Genetics, Department of Biology, University of Turku, FIN-20014 Turku, Finland; e-mail: niina.snall@utu.fi \\ ${ }^{2}$ Section of Ecology, Department of Biology, University of Turku, FIN-20014 Turku, Finland \\ ${ }^{3}$ Department of Medical Genetics, University of Turku, FIN-20014 Turku, Finland
}

Key words. Epirrita autumnata, Lepidoptera, mitochondrial DNA, population structure, dispersal

\begin{abstract}
Analysis of the mitochondrial DNA (mtDNA) control region (CR) was used to examine the dispersal of females of a geometrid moth, Epirrita autumnata, in Fennoscandia. A 542-bp-portion of the CR of 200 individuals from four northern and four southern localities was sequenced. The mtDNA CR of E. autumnata contains a substantial amount of variation as a total of 108 mtDNA haplotypes were observed. Between the northern and the southern localities $(\sim 1100 \mathrm{~km})$, there was a moderate level of genetic differentiation $\left(F_{\mathrm{ST}}=0.128\right)$. The amount of variation in the mtDNA CR of E. autumnata was lower in the north than in the south. The reduction in genetic variability may result from a combination of historical bottlenecks that date back to the post-glacial recolonization of Fennoscandia and, present-day bottlenecks due to the northern E. autumnata populations experiencing repeated outbreaks followed by collapse in population size. On a small spatial scale $(0.6-19 \mathrm{~km})$, within the northern and southern areas, no genetic differentiation was detected suggesting ongoing gene flow due to the dispersal of E. autumnata females among the localities. This finding was contrary to our earlier expectation of poor flying ability of E. autumnata females.
\end{abstract}

\section{INTRODUCTION}

Dispersal is not usually addressed in field studies on insect population ecology. In the population dynamic context, dispersal of females is the decisive factor, because it is the females that lay the eggs. For our study species, the geometrid moth Epirrita autumnata (Borkhausen, 1794), there are many local ecological studies and studies of population dynamics (e.g. Kaitaniemi et al., 1999; Tanhuanpää et al., 1999, 2001, 2003; for general reviews, see Haukioja et al., 1988; Ruohomäki et al., 2000). We attempted to measure the dispersal of females directly but failed because in mark-release-recapture studies E. autumnata females are not efficiently recaptured by light traps. In addition to their inefficiency the light traps are inconvenient at large spatial scales, e.g. several kilometres. The number of marked females in an area has to be remarkably high if one is to be caught by a remote light trap. Therefore, we attempted to estimate the dispersal of E. autumnata females indirectly, using variation in mitochondrial DNA (mtDNA). Maternal inheritance makes mtDNA a potentially valuable tool for population studies (see e.g. Avise, 1994). Analyses of mtDNA have been used in several studies of the intraspecific genetic relationships and population structure of insects (e.g. Hale \& Singh, 1991; de la Rúa et al., 2000; Mardulyn, 2001; Kankare et al., 2002).

Fluctuation in population density can sometimes contribute to rapid microevolutionary changes. In insects, the fluctuations in population density in outbreak populations can be enormous (see e.g. Berryman, 1987) and have con- sequences at the molecular level as outbreaks are followed by a collapse in population size, leading to a population bottleneck and a decline in genetic variability (Futuyma, 1998). Indeed, E. autumnata has inspired researchers particularly because it has cyclical population dynamics. In north-European mountain birch forests the length of the cycle is a $2-10$ years (Tenow, 1972; Haukioja et al., 1988). During the low density phase it is difficult to find one larva on a dozens mountain birches whereas during some outbreaks, defoliation by millions of E. autumnata larvae has caused severe damage to mountain birch forests, even the death of forests over vast areas (e.g. Tenow, 1972; Kallio \& Lehtonen, 1973). In contrast to the northern populations the density in more southern populations, e.g. in southern Finland, is relatively stable and without outbreaks (Tenow, 1972; Tanhuanpää et al., 1999). Therefore, unlike the southern populations those in the north may experience periodical bottlenecks. Thus, in addition to spatial scales relevant to the dispersal of females, we include in this paper an analysis of mtDNA variation in the northern and southern populations of E. autumnata.

\section{MATERIAL AND METHODS}

\section{Study species}

Epirrita autumnata is an abundant polyphagous geometrid widely distributed in the Holarctic region, including Fennoscandia (Finland, Sweden and Norway). In spring the larvae hatch and feed on the leaves of deciduous trees and shrubs. The larvae pupate on the ground in the litter and the adults emerge and fly in autumn. 


\section{Samples}

A total of 200 individuals of E. autumnata were analysed. All were collected by hand as larvae from Betula pubescens Ehrh. between 1998 and 2002 from eight geographically separated Fennoscandian localities (Table 1). Four of the localities were in southern and the other four in northern Fennoscandia. The southern localities in Vahto, coded Va36, Va361, and Va36e, were separated by 0.6 to $1.5 \mathrm{~km}$ from each other; Masku, M, is $\sim 18 \mathrm{~km}$ from the three Vahto localities. The three northern localities in Hana Norway, Lk, L, and LSB, were separated by 0.9 to $2.3 \mathrm{~km}$ from each other. The fourth Norwegian locality, Boftsa, coded N4, is situated $\sim 19 \mathrm{~km}$ from Hana. The distance between the northern and southern localities was $\sim 1100 \mathrm{~km}$. After collection, as described earlier (Snäll et al., 2002), the southern E. autumnata larvae were stored at $-20^{\circ} \mathrm{C}$, while the northern larvae were also first stored at $-20^{\circ} \mathrm{C}$ but then kept at $5^{\circ} \mathrm{C}$ during transportation to Turku, Finland, after which they were again stored at $-20^{\circ} \mathrm{C}$.

\section{Molecular techniques}

Our previous study (Snäll et al., 2002) indicates that the mtDNA control region (CR) is likely to contain sufficient variation for investigating the population structure of E. autumnata. The entire CR sequence of 16 individuals was determined. This revealed four mtDNA lineages that differed from each other with an average sequence divergence of $7.5 \%$, which was almost 4 times higher than that within the lineages. In the present study, the 5' part of the E. autumnata CR, domain I, which consists mainly of nonrepetitive sequences, was chosen as a marker.

DNA was extracted, and a $\sim 1100-1300$ bp fragment containing the entire mtDNA CR was amplified as described previously (Snäll et al., 2002). A manual hot-start with $100 \mathrm{ng}$ of the template DNA was performed to improve the specificity of the PCR reaction and to increase the yield. Sixteen individuals (eight northern and eight southern) from our earlier study (Snäll et al., 2002) were included in this study and, like those, also 28 new individuals (14 northern and 14 southern) were cloned prior to sequencing. The remaining 156 individuals were successfully directly sequenced after purification of the desired PCR fragment from the agarose gel with GFX PCR ${ }^{\mathrm{TM}}$ DNA and Gel Band Purification Kit (Amersham Pharmacia Biotech Inc., Piscataway, N.J.).

The sequencing of the $\mathrm{CR}$ clones and PCR products was performed on an automatic ABI PRISM ${ }^{\mathrm{TM}} 377$ DNA Sequencer using ABI PRISM ${ }^{\circledR}$ BigDye $^{\mathrm{TM}}$ and dRhodamine Terminator Cycle Sequencing Kits (Applied Biosystems, Foster City, CA), of which the latter chemistry was better for the AT-rich insect mtDNA CR templates. Both the clones and PCR products were sequenced in only one direction with their forward PCR primer, because no reverse sequencing primer could be designed in the middle of the AT-rich CR. The 28 cloned CR sequences were determined from one randomly chosen clone per sample.

\section{Data analysis}

In the 200 E. autumnata originating from eight Fennoscandian localities, the total length of the CR portion analysed ranged from 530 to $532 \mathrm{bp}$ covering the 5' part of the CR up to the beginning of the AT-array. The sequences were edited using the Sequencher ${ }^{\mathrm{TM}}$ v.3.1.1 program (Gene Codes Corp., Ann Arbor, MI). Because of the considerable variation in length (long A- and T-runs) over the region studied, sequences were aligned visually. Using this method, the final length of the consensus sequence was extended to $542 \mathrm{bp}$, which hereafter is referred to as the length of the region analysed.
Table 1. Details of the eight Fennoscandian localities sampled.

\begin{tabular}{llccc}
\hline Locality & Code & Coordinates & $\begin{array}{c}\text { Sample } \\
\text { size }\end{array}$ & $\begin{array}{c}\text { Sampling } \\
\text { year }\end{array}$ \\
\hline $\begin{array}{l}\text { North (Norway) } \\
\text { Hana }\end{array}$ & Lk & $70^{\circ} 14^{\prime} \mathrm{N}, 28^{\circ} 27^{\prime} \mathrm{E}$ & 25 & June 2000 \\
Hana & LSB & $70^{\circ} 14^{\prime} \mathrm{N}, 28^{\circ} 27^{\prime} \mathrm{E}$ & 25 & June 2002 \\
Hana & $\mathrm{L}$ & $70^{\circ} 14^{\prime} \mathrm{N}, 28^{\circ} 29^{\prime} \mathrm{E}$ & 25 & June 2002 \\
Boftsa & $\mathrm{N} 4$ & $70^{\circ} 23^{\prime} \mathrm{N}, 28^{\circ} 10^{\prime} \mathrm{E}$ & 25 & June 2000 \\
South (Finland) & & & & \\
Vahto & $\mathrm{Va36}$ & $60^{\circ} 40^{\prime} \mathrm{N}, 22^{\circ} 21^{\prime} \mathrm{E}$ & 25 & May 2000 \\
& & & & May 1998* \\
Vahto & $\mathrm{Va3} 61$ & $60^{\circ} 40^{\prime} \mathrm{N}, 22^{\circ} 20^{\prime} \mathrm{E}$ & 25 & May 2002 \\
Vahto & $\mathrm{Va36e}$ & $60^{\circ} 39^{\prime} \mathrm{N}, 22^{\circ} 21^{\prime} \mathrm{E}$ & 25 & May 2002 \\
Masku & $\mathrm{M}$ & $60^{\circ} 23^{\prime} \mathrm{N}, 22^{\circ} 07^{\prime} \mathrm{E}$ & 25 & May 2000 \\
\hline
\end{tabular}

* three individuals were reared in the laboratory to adulthood before storage at $-20^{\circ} \mathrm{C}$.

The population genetic analyses were carried out using the Arlequin 2.0 software (Schneider et al., 2000), where transitions are given the weight 2.0. The population genetic structure based on the haplotype frequencies with 10100 permutations was inferred by using AMOVA (Excoffier et al., 1992). Population comparisons included the calculation of $F_{\text {ST }}$ statistics, the interpopulation component of genetic variation (Slatkin, 1995) and pairwise differences between populations (Nei \& Li, 1979). At the intra-population level, the number of polymorphic sites $(S)$, haplotype $(H)$ and nucleotide $(\pi)$ diversities $(\mathrm{Nei}, 1987)$ and the mean number of pairwise differences $(d x)$ (Tajima, 1983) among haplotypes were determined. The presence of historic population bottlenecks was estimated using Tajima's D statistics, the test for selective neutrality (Tajima, 1989). The differences in mtDNA lineage frequencies between northern and southern areas were compared using Fisher's Exact Test for lineages 2 and 6 (small expected frequencies) and Chi Square Test for lineages $1,3,4$, and 5 .

\section{RESULTS}

\section{CR sequence polymorphisms}

There was considerable length variation over the region studied, mainly resulting from insertions and deletions (indels) embedded in long homopolymer runs. The sequences were aligned so that the length-variable A- and T-runs did not overlap, avoiding transversions and emphasizing the occurrence of indels, some of which are evolutionarily informative. In the 200 aligned E. autumnata sequences (Appendix), there were 103 variable sites with two different substitutions at four sites, and a substitution and an indel at two sites. Altogether 87 nucleotide substitutions and 22 indels were found and of these 109 different variants, 46 were unique. The transition / transversion ratio was $2.0: 1.0$. Epirrita autumnata from the south were more polymorphic than those from the north, having an average of 62.5 polymorphic sites compared to 32.0 (Table 2). The mean number of pairwise differences among localities was 1.6 times higher in the south than in the north. The mean nucleotide diversity value in the north was $0.0245( \pm 0.0127)$ and in the south 0.0385 $( \pm 0.0196)$. 
TABLE 2. The sample size (n), number of polymorphic sites $(S)$, number of haplotypes $(\mathrm{nH})$, haplotype diversity $(H)$, nucleotide diversity $(\pi)$, mean number of pairwise differences $(d x)$ and Tajima's D statistics for E. autumnata at the eight localities.

\begin{tabular}{|c|c|c|c|c|c|c|c|}
\hline Locality & $\mathrm{n}$ & $S$ & $\mathrm{nH}$ & $H$ & $\pi$ & $d x$ & $\mathrm{D}$ \\
\hline \multicolumn{8}{|l|}{ North } \\
\hline $\mathrm{Lk}$ & 25 & 37 & 19 & 0.9733 & 0.0281 & 15.12 & $3.30 * * *$ \\
\hline LSB & 25 & 29 & 17 & 0.9600 & 0.0209 & 11.25 & $2.74 * *$ \\
\hline $\mathrm{L}$ & 25 & 28 & 16 & 0.9533 & 0.0229 & 12.37 & $3.26^{* * *}$ \\
\hline N4 & 25 & 34 & 15 & 0.9433 & 0.0262 & 14.10 & $2.68 * *$ \\
\hline \multicolumn{8}{|l|}{ South } \\
\hline Va36 & 25 & 68 & 21 & 0.9767 & 0.0351 & 18.93 & $0.20^{\mathrm{NS}}$ \\
\hline Va361 & 25 & 58 & 18 & 0.9667 & 0.0399 & 21.52 & $1.77 *$ \\
\hline Va36e & 25 & 59 & 20 & 0.9733 & 0.0388 & 20.91 & $1.12^{\mathrm{NS}}$ \\
\hline M & 25 & 65 & 24 & 0.9967 & 0.0403 & 21.63 & $1.00^{\mathrm{NS}}$ \\
\hline mean North & - & 32 & 17 & 0.9575 & 0.0245 & 13.21 & - \\
\hline mean South & - & 63 & 21 & 0.9784 & 0.0385 & 20.75 & - \\
\hline
\end{tabular}

A total of 108 haplotypes, Ea1-Ea108, were defined (Appendix). The majority, 74.1\% (80/108), of the haplotypes were unique, $9.3 \%(10 / 108)$ were shared between the south and the north, and none were common at all localities. The number of haplotypes at a locality ranged from 15 to 24, the average being 17 in the north and 21 in the south (Table 2). The mean haplotype diversity value in the north and in the south was $0.9575( \pm 0.0127)$ and $0.9784( \pm 0.0198)$, respectively.

\section{Population structure}

The majority of the genetic variation $(87.2 \%)$ occurred within localities, and the rest was due to differences between the north and the south. The combined north vs. south $F_{\mathrm{ST}}$ value $0.128(p<0.05)$ indicates a moderate level of differentiation over the large geographical scale studied $(\sim 1100 \mathrm{~km})$. No genetic differentiation $\left(F_{\mathrm{SC}}=\right.$ $-0.011, p=0.87$ ) was found among the localities within the two geographical groups on a small spatial scale $(0.6$ $-19 \mathrm{~km})$. The pairwise $F_{\mathrm{ST}}$ values between the localities showed significant differences between the northern and southern populations (Table 3). The Tajima's D values indicated significant historical population bottlenecks had occurred at all northern localities, and one of the southern localities, Va361 (Table 2).

\section{mtDNA lineages}

In our previous study (Snäll et al., 2002) four E. autumnata mtDNA lineages based on the CR variation of 16 individuals were identified. In the present study, two additional lineages were identified (Appendix and Table 4). The previously described lineage 1 was split into two lineages numbered 1 and 5. In addition, another new mtDNA lineage, numbered 6, emerged. Lineages 2, 3 and 4 remained as previously described. Each lineage was defined by a specific variant pattern found in every individual sequence assigned to that particular lineage (Table 4). These patterns consisted of two to 25 variants of which zero to 13 were solely lineage specific. There were also nine indels in long A- and T-runs, which were informative in the mtDNA lineage definitions. The sequence divergence within and between lineages, respectively, ranged from $0.2 \%$ (lineage 6 ) to $4.3 \%$ (lineage 4 ) (average of 3.1\%), and from 3.7\% (lineage 1 vs. lineage 5 ) to $11.6 \%$ (lineage 4 vs. lineage 6 ) (average of $7.8 \%$ ).

The Fennoscandian E. autumnata showed geographical variation in the frequencies of the mtDNA lineages at the large spatial scale (Table 5). Lineages 2 and 6 were specific to the south with a total of 13 individuals. The other four lineages were represented in both the southern and northern populations. Lineage 1 was predominantly northern with statistical significance $(p<0.001)$, as 58 out of 100 individuals belonged to that lineage, whereas in the south, there were only six out of 100 individuals assigned to this lineage. Lineage 4 was significantly ( $p<$ $0.001)$ more frequent in the south than in the north. The other two lineages, lineages 3 and 5, were also dominated by southern E. autumnata, but not significantly so. Among localities in the north or south, there were no, or only minor, differences in the frequencies of the mtDNA lineages (Table 5).

\section{DISCUSSION}

A moderate amount of genetic differentiation in the mtDNA CR of E. autumnata was found at the large spatial scale, i.e. between the southern and northern

TABLE 3. Pairwise $F_{\text {ST }}$ values among localities.

\begin{tabular}{|c|c|c|c|c|c|c|c|}
\hline Locality & LSB & $\mathrm{L}$ & N4 & Va36 & Va361 & Va36e & M \\
\hline \multicolumn{8}{|l|}{ North } \\
\hline $\mathrm{Lk}$ & $0.0101^{\mathrm{NS}}$ & $-0.0132^{\mathrm{NS}}$ & $0.0079^{\mathrm{NS}}$ & $0.0649^{*}$ & $0.0811^{* *}$ & $0.0479 *$ & $0.0516^{*}$ \\
\hline LSB & & $-0.0238^{\mathrm{NS}}$ & $-0.0150^{\mathrm{NS}}$ & $0.1894 * * *$ & $0.1892 * * *$ & $0.1474 * *$ & $0.1552 * * *$ \\
\hline $\mathrm{L}$ & & & $-0.0131^{\mathrm{NS}}$ & $0.1473 * *$ & $0.1585 * * *$ & $0.1202 * *$ & $0.1241 * *$ \\
\hline N4 & & & & $0.1601 * * *$ & $0.1563 * * *$ & $0.1163^{* *}$ & $0.1340 * *$ \\
\hline \multicolumn{8}{|l|}{ South } \\
\hline Va36 & & & & & $-0.0146^{\mathrm{NS}}$ & $-0.0127^{\mathrm{NS}}$ & $-0.0171^{\mathrm{NS}}$ \\
\hline Va361 & & & & & & $-0.0146^{\mathrm{NS}}$ & $-0.0169^{\mathrm{NS}}$ \\
\hline Va36e & & & & & & & $-0.0112^{\mathrm{NS}}$ \\
\hline M & & & & & & & \\
\hline
\end{tabular}


TABLE 4. Variant patterns defining six E. autumnata mtDNA lineages (See Appendix). Lineage-specific variants are in italics and bold.

\begin{tabular}{|c|c|c|}
\hline MtDNA lineage & Number of individuals & $\begin{array}{c}\text { Reference nucleotides } \\
\text { ATTTGCAGGGGTAGAGATATTGTATAT-AA-TT-TAGGGTTTGGTAG }\end{array}$ \\
\hline 1 & 64 & 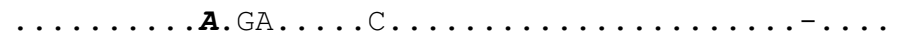 \\
\hline 2 & 8 & 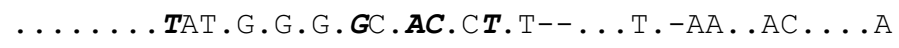 \\
\hline 3 & 43 & 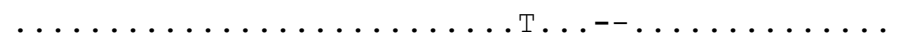 \\
\hline 4 & 63 & 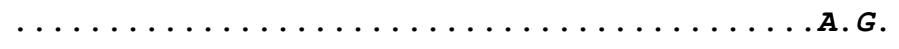 \\
\hline 5 & 17 & 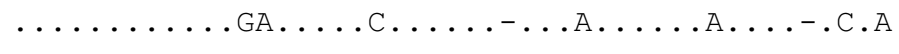 \\
\hline 6 & 5 & 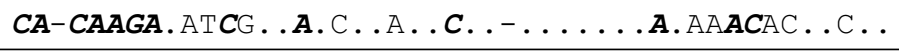 \\
\hline
\end{tabular}

Dot; sequence identity with reference nucleotide.

localities, that are located more than one thousand kilometres apart. In contrast, no or only little differentiation was found at the local scale, i.e. among localities separated from each other by $0.6-19$ kilometres. The latter suggests ongoing gene flow due to the dispersal of females among the localities.

\section{Dispersal of $E$. autumnata females}

Ongoing gene flow enough to prevent genetic differentiation of populations at a local scale is contrary to our earlier expectation of the poor dispersal ability of $E$. autumnata females. This expectation was based on the following observations. First, E. autumnata is a capital breeder relying on larval-derived resources for reproduction (Tammaru \& Haukioja, 1996); this means that a newly-emerged female has a heavy load of eggs. Moreover, E. autumnata females have smaller wings than the otherwise similar-sized males. Together these facts indicate females are weak flyers (see also Itämies et al., 1995). Second, during peak population densities few $E$. autumnata adults are caught in light traps located a few hundred metres from traps in which large numbers of both females and males are caught (Itämies et al., 1995). This implies low dispersal from where the moths developed as larvae. Third, in a mark-release-recapture study of laboratory-reared moths, some females were recaptured after one to two nights in the same hectare within which they were released, and had only few eggs left. This indicates that females have no strong tendency to disperse before oviposition and suggests the absence of an obligatory dispersal phase before the onset of oviposition. However, old E. autumnata females with lighter egg loads are likely to have improved flight ability and therefore may lay the rest of their eggs further away from where they developed. Although only few eggs are likely to reach other habitats in this way, the consequence for gene flow could be important if they survive and the offspring successfully reproduce in the new habitat.

Another explanation for the lack of genetic differentiation at a local scale could be larval dispersal by ballooning, i.e. the production of a silken thread by larvae and transportation by the wind. In E. autumnata, however, the dispersal of larvae by ballooning seems to occur only over short distances. For example, when over-wintering eggs were killed by low temperatures at low altitudes, the boundary between defoliated and not-defoliated mountain birch forest remained sharp in the following summers (Tenow, 1975; Tenow \& Holmgren, 1987). Further, results for other species of Lepidoptera with ballooning

TABLE 5. Frequencies of the E. autumnata mtDNA lineages (percentage values in parentheses) at the eight localities and totals in the north and south. In the last column, the statistical significance (Fisher's Exact Test for lineages 2 and 6, and Chi Square Test for lineages 1,3,4, and 5) of the differences between the north and the south is indicated.

\begin{tabular}{|c|c|c|c|c|c|c|c|c|c|c|c|}
\hline \multirow{2}{*}{$\begin{array}{l}\text { MtDNA } \\
\text { lineage }\end{array}$} & \multicolumn{4}{|c|}{ Northern localities } & \multicolumn{4}{|c|}{ Southern localities } & \multirow{2}{*}{ North } & \multirow{2}{*}{ South } & \multirow{2}{*}{$\begin{array}{c}\text { Statistical } \\
\text { significance }\end{array}$} \\
\hline & Lk & LSB & $\mathrm{L}$ & N4 & Va36 & Va361 & Va36e & $\mathrm{M}$ & & & \\
\hline 1 & $\begin{array}{c}12 \\
(48 \%)\end{array}$ & $\begin{array}{c}17 \\
(68 \%)\end{array}$ & $\begin{array}{c}16 \\
(64 \%)\end{array}$ & $\begin{array}{c}13 \\
(52 \%)\end{array}$ & $\begin{array}{c}2 \\
(8 \%)\end{array}$ & 0 & $\begin{array}{c}1 \\
(4 \%)\end{array}$ & $\begin{array}{c}3 \\
(12 \%)\end{array}$ & 58 & 6 & $* * *$ \\
\hline 2 & 0 & 0 & 0 & 0 & $\begin{array}{c}1 \\
(4 \%)\end{array}$ & $\begin{array}{c}3 \\
(12 \%)\end{array}$ & $\begin{array}{c}1 \\
(4 \%)\end{array}$ & $\begin{array}{c}3 \\
(12 \%)\end{array}$ & 0 & 8 & $*$ \\
\hline 3 & $\begin{array}{c}5 \\
(20 \%)\end{array}$ & $\begin{array}{c}5 \\
(20 \%)\end{array}$ & $\begin{array}{c}5 \\
(20 \%)\end{array}$ & $\begin{array}{c}4 \\
(16 \%)\end{array}$ & $\begin{array}{c}6 \\
(24 \%)\end{array}$ & $\begin{array}{c}6 \\
(24 \%)\end{array}$ & $\begin{array}{c}8 \\
(32 \%)\end{array}$ & $\begin{array}{c}4 \\
(16 \%)\end{array}$ & 19 & 24 & NS \\
\hline 4 & $\begin{array}{c}7 \\
(28 \%)\end{array}$ & $\begin{array}{c}3 \\
(12 \%)\end{array}$ & $\begin{array}{c}4 \\
(16 \%)\end{array}$ & $\begin{array}{c}4 \\
(16 \%)\end{array}$ & $\begin{array}{c}12 \\
(48 \%)\end{array}$ & $\begin{array}{c}11 \\
(44 \%)\end{array}$ & $\begin{array}{c}9 \\
(36 \%)\end{array}$ & $\begin{array}{c}13 \\
(52 \%)\end{array}$ & 18 & 45 & $* * *$ \\
\hline 5 & $\begin{array}{c}1 \\
(4 \%)\end{array}$ & 0 & 0 & $\begin{array}{c}4 \\
(16 \%)\end{array}$ & $\begin{array}{c}3 \\
(12 \%)\end{array}$ & $\begin{array}{c}4 \\
(16 \%)\end{array}$ & $\begin{array}{c}4 \\
(16 \%)\end{array}$ & $\begin{array}{c}1 \\
(4 \%)\end{array}$ & 5 & 12 & NS \\
\hline 6 & 0 & 0 & 0 & 0 & $\begin{array}{c}1 \\
(4 \%)\end{array}$ & $\begin{array}{c}1 \\
(4 \%)\end{array}$ & $\begin{array}{c}2 \\
(8 \%)\end{array}$ & $\begin{array}{c}1 \\
(4 \%)\end{array}$ & 0 & 5 & NS \\
\hline $\begin{array}{l}\text { Total number } \\
\text { of individuals }\end{array}$ & 25 & 25 & 25 & 25 & 25 & 25 & 25 & 25 & 100 & 100 & - \\
\hline
\end{tabular}

NS, not significant; ${ }^{* * *}, p<0.001 ;{ }^{*}, p<0.05$ 
larvae suggest that the dispersal distances are too short to affect local population dynamics (Liebhold \& Elkinton, 1990; Harrison, 1994; Dwyer \& Elkinton, 1995; but see Edland, 1971).

To the best of our knowledge there are no studies on the population genetics of geometrids utilizing mtDNA CR sequence analyses. Previous studies on the population structure of geometrids were conducted using allozyme variation (Van San \& Šula, 1993; Woiwod \& Wynne, 1994; Van Dongen, 1997; Wynne et al., 2003) and therefore cannot be compared with the present study. However, whether the studies are based on variation in allozymes or DNA there are certain disadvantages in applying indirect methods to studies conducted on ecological time scales. For example, a lack of resolution of a DNA marker as well as lack of power of the statistical analysis could limit the interpretive value of estimates of gene flow (Bossart \& Prowell, 1998). Moreover, a recent gene flow is difficult to distinguish from an historical one (Slatkin \& Madison, 1989). Therefore, there is need to combine successful field studies with molecular data in order to get more precise information about ecological issues such as the distance a species may disperse.

\section{Lower mtDNA diversity in the north}

The variation in mtDNA CR of E. autumnata was lower in the north than in the south. The nucleotide diversity in the northern populations was only $64.1 \%$ of that in the south (Table 2), and two out of six mtDNA lineages were absent from the northern localities (Table 5). Further, the existence of one strongly predominating mtDNA lineage reflects the smaller long-term effective population size (Hale \& Singh, 1991) of the fluctuating northern E. autumnata compared to the more stable southern populations.

The mtDNA, because its effective population size is a quarter of that of nuclear DNA (Birky et al., 1983), is expected to be very sensitive to the bottleneck phenomenon. First, the decrease in genetic variability in the north, a phenomenon frequently observed in population structure surveys of European species (e.g. Schmitt \& Seitz, 2002; Merilä et al., 1996; Cooper et al., 1995), is predicted to be a consequence of post-Pleistocene colonization events in which northward-expanding populations are likely to have experienced at the edge of this range several consecutive bottleneck events, which resulted in the loss of a large amount of the original genetic variability (Avise, 2000; Hewitt, 1996). In our study, Tajima's D values indicate historical population bottlenecks occurred at all the northern localities (Table 2). Second, drastic declines in population size, as exhibited periodically by the northern populations, are always thought to reduce variability in the mtDNA (Futuyma, 1998). However, because temporal variation has not been studied it is not possible to distinguish between the contributions of historical and present-day bottlenecks. Compared to southern E. autumnata, the reduced mtDNA diversity in northern populations could result from several bottleneck events, both historical and cyclical, over a long time scale.
In conclusion, we used mtDNA CR sequence data to indirectly estimate the dispersal of E. autumnata females over small distances. The results of the present analysis suggest females disperse for enough to homogenize population structure over distances of up to at least $19 \mathrm{~km}$. This is contrary to our earlier expectations based on the assumption that E. autumnata females are poor flyers, and without supporting field studies these results have to be interpreted with caution. Our large-scale study revealed that the mtDNA CR of the northern E. autumnata is less variable than that of the southern population. This could be due to the combined effects of historical bottlenecks related to the postglacial range expansion and recurrent bottlenecks related to the cyclicity of northern E. autumnata populations.

ACKNOWLEDGEMENTS. We thank all those who participated in the collection of larvae in the field. We also thank M. Kleemola and D. Tringham for checking the use of language. The study was financially supported by the Academy of Finland (project 48697), and by grants to N.S. from the Emil Aaltonen Foundation, the Finnish Cultural Foundation, the Turku University Foundation, and the Turku Finnish University Society.

\section{REFERENCES}

Avise J.C. 1994: Molecular Markers, Natural History and Evolution. Chapman \& Hall, New York, 511 pp.

Avise J.C. 2000: Phylogeography: The History and Formation of Species. 2nd ed. Harvard University Press, Cambridge, Massachusetts, USA, $447 \mathrm{pp}$.

Berryman A.A. 1987: The theory and classification of outbreaks. In Barbosa P. \& Schultz J.C. (eds): Insect Outbreaks. Academic Press, San Diego, pp. 3-30.

Birky C.W., Maruyama T. \& Fuerst P. 1983: An approach to population and evolutionary genetic theory for genes in mitochondria and chloroplasts, and some results. Genetics 103: 513-527.

Bossart J.L. \& Prowell D.P. 1998: Genetic estimates of population structure and gene flow: limitations, lessons and new directions. Trends Ecol. Evol. 13: 202-206.

Cooper S.J.B., Ibrahim K.M. \& Hewitt G.M. 1995: Postglacial expansion and genome subdivision in the European grasshopper Chorthippus parallelus. Mol. Ecol. 4: 49-60.

DwYer G. \& ElKINTON J.S. 1995: Host dispersal and the spatial spread of insect pathogens. Ecology 76: 1262-1275.

EDLAND T. 1971: Wind dispersal of the winter moth larvae Operophtera brumata L. (Lep., Geometridae) and its relevance to control measures. Norsk Entomol. Tidsskr. 18: 103-105.

Excoffier L., Smouse P.E. \& Quatro J.M. 1992: Analysis of molecular variance inferred from metric distances along DNA haplotypes: application to human mitochondrial DNA restriction data. Genetics 131: 479-491.

FutuYMA D.J. 1998: Evolutionary Biology. 3rd ed., Sinauer Associates, Sunderland, Massachusetts, USA, 763 pp.

HALE L.H. \& Singh R.S. 1991: A comprehensive study of genic variation in natural populations of Drosophila melanogaster. IV. Mitochondrial DNA variation and the role of history vs. selection in the genetic structure of geographic populations. Genetics 129: 103-117.

HARRISON S. 1994: Resources and dispersal as factors limiting a population of the tussock moth (Orgyia vetusta), a flightless defoliator. Oecologia 99: 29-37. 
Haukioja E., Neuvonen S., Hanhimäki S. \& Niemelä P. 1988: The autumnal moth in Fennoscandia. In Berryman A.A. (ed): Dynamics of Forest Insect Populations. Patterns, Causes, and Implications. Plenum Press, New York, pp. 163-178.

HewitT G.M. 1996: Post-glacial re-colonization of European biota. Biol. J. Linn. Soc. 68: 87-112.

Itämies J., Pulliainen E. \& Siekkinen J. 1995: Mobility of Epirrita autumnata (Lepidoptera, Geometridae), as indicated by altitudinal light trap sampling in Finnish Forest Lapland. Oecol. Mont. 4: 27-30.

Kaitaniemi P., RuohomäKi K., Tammaru T. \& Haukioja E. 1999: Induced resistance of host tree foliage during and after a natural insect outbreak. J. Anim. Ecol. 68: 382-389.

Kallio P. \& Lehtonen J. 1973: Birch forest damage caused by Oporinia autumnata (Bkh.) in 1965-1966 in Utsjoki, N-Finland. Rep. Kevo Subarctic Res. Stat. 10: 55-69.

Kankare M., VÁrkonyi G. \& Saccheri I. 2002: Genetic differentiation between alternate-year cohorts of Xestia tecta. Hereditas 136: 169-176.

Liebhold A.M. \& Elkinton J.S. 1990: Models of the spatial dynamics of epidemic gypsy moth populations. In Watt A.D., Leather S.R., Hunter M.D. \& Kidd N.A.C. (eds): Population Dynamics of Forest Insects. Intercept, Andover, pp. 359-367.

Mardulyn P. 2001: Phylogeography of the Vosges mountains populations of Gonioctena pallida (Coleoptera: Chrysomelidae): a nested clade analysis of mitochondrial DNA haplotypes. Mol. Ecol. 10: 1751-1763.

Merilä J., BJöRKLund M. \& BAKER A.J. 1996: Genetic population structure and gradual northward decline of genetic variability in the greenfinch (Carduelis chloris). Evolution 50: 2548-2557.

NeI M. 1987: Molecular Evolutionary Genetics. Columbia University Press, New York, 512 pp.

Nei M. \& Li W.H. 1979: Mathematical model for studying genetic variation in terms of restriction endonucleases. Proc. Natl. Acad. Sci. USA 76: 5269-5273.

De la Rúa P., Simon U.E., Tilde A.C., Moritz R.F.A. \& Fuchs S. 2000: MtDNA variation in Apis cerana populations from the Philippines. Heredity 84: 124-130.

Ruohomäki K., Tanhuanpää M., Ayres M.P., Kaitaniemi P., Tammaru T. \& Haukioja E. 2000: Causes of cyclicity of Epirrita autumnata (Lepidoptera, Geometridae): grandiose theory and tedious practice. Popul. Ecol. 42: 211-223.

Sснмiтt T. \& Seitz A. 2002: Postglacial distribution area expansion of Polyommatus coridon (Lepidoptera: Lycaenidae) from its Ponto-Mediterranean glacial refugium. Heredity 89: 20-26.

SChNeIDER S., Roessli D. \& Excoffier L. 2000: Arlequin. Software for population genetics data analysis. Version 2.000, Genetics and Biometry Laboratory, University of Geneve, Switzerland.

SLATKIN M. 1995: A measure of population subdivision based on microsatellite allele frequencies. Genetics 139: 457-462.

SLATKIN M. \& MAdDISON W.P. 1989: A cladistic measure of gene flow inferred from the phylogenies of alleles. Genetics 123: 603-613.
Snäll N., Huoponen K., Savontaus M.-L. \& Ruohomäki K. 2002: Tandem repeats and length variation in the mitochondrial DNA control region of Epirrita autumnata (Lepidoptera: Geometridae). Genome 45: 855-861.

TалIMA F. 1983: Evolutionary relationships of DNA sequences in infinite populations. Genetics 105: 437-460.

TAJIMA F. 1989: The effect of change in population size on DNA polymorphism. Genetics 123: 597-601.

TAMmaru T. \& Haukioja E. 1996: Capital breeders and income breeders among Lepidoptera: consequences to population dynamics. Oikos 77: 561-564.

TanhuanpäÄ M., RuohomäKi K., Kaitaniemi P. \& Klemola T. 1999: Different impact of pupal predation on populations of Epirrita autumnata (Lepidoptera; Geometridae) within and outside the outbreak range. J. Anim. Ecol. 68: 562-570.

TanhuanpäÄ M., RuohomäKi K. \& UusipaikKa E. 2001: High larval predation rate in non-outbreaking populations of a geometrid moth. Ecology 82: 281-289.

Tanhuanpää M., RuohomäKi K. \& Kaitaniemi P. 2003: Influence of adult and egg predation on reproductive success of Epirrita autumnata (Lepidoptera: Geometridae). Oikos 102: 263-278.

TeNOw O. 1972: The outbreaks of Oporinia autumnata Bkh. and Operophthera spp. (Lep., Geometridae) in the Scandinavian mountain chain and northern Finland 1862-1968. Zool. Bidr. Upps. (Suppl. 2): 1-107.

TENOW O. 1975: Topographical dependence of an outbreak of Oporinia autumnata Bkh. (Lep., Geometridae) in a mountain birch forest in northern Sweden. Zoon 3: 85-110.

Tenow O. \& Holmgren B. 1987: Low winter temperatures and an outbreak of Epirrita autumnata along a valley of Finnmarksvidda, the "Cold Pole" of northern Fennoscandia. In Alexandersson H. \& Holmgren B. (eds): Climatological Extremes in the Mountains. Physical Background, Geomorphological and Ecological Consequences. UNGI-rapport 65. Department of Physical Geography, Uppsala University, Uppsala, Sweden, pp. 203-216.

Van Dongen S. 1997: The Population Structure of the Winter Moth Operophtera brumata in Relation to Local Adaptation and Habitat Fragmentation. PhD thesis, University of Antwerpen, Antwerpen.

VAN SAN N. \& Šula J. 1993: Allozyme variation in the winter moth, Operophtera brumata (Lepidoptera: Geometridae), in isolated populations. Eur. J. Entomol. 90: 303-310.

WoIwOD L.P. \& WYNNE I.R. 1994: The distribution and genetic structure of farmland moth communities. In: The Fragmentation in Agricultural Landscapes. Proceedings of the third annual conference of IALE (UK), Preston 13-14th September 1994.

WynNe I.R., LoXdale H.D., BRookes C.P. \& Woiwod I.P. 2003: Genetic structure of fragmented November moth (Lepidoptera: Geometridae) populations in farmland. Biol. J. Linn. Soc. 78: $467-478$.

Received June 22, 2004; revised September 16, 2004; accepted October 25, 2004 


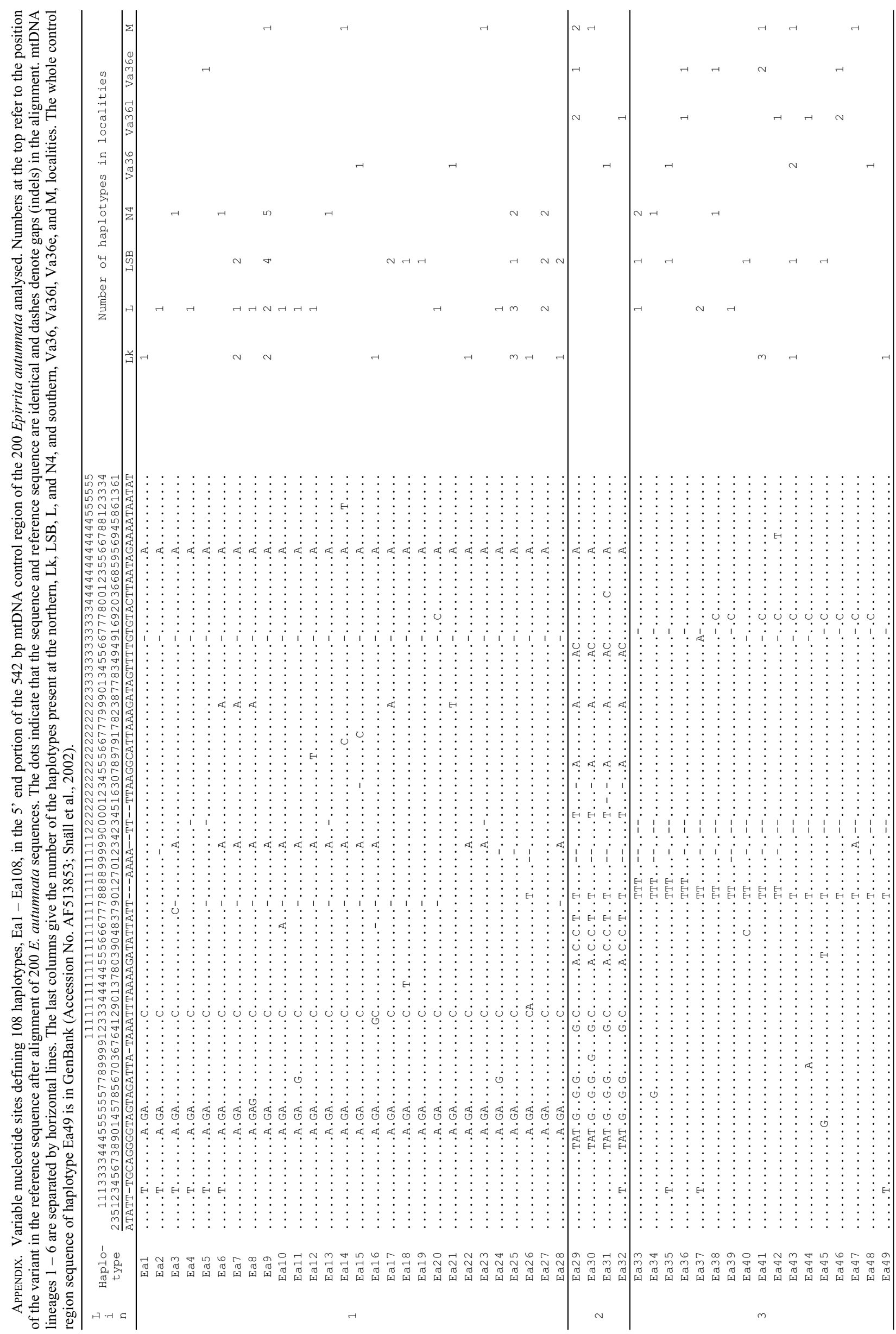




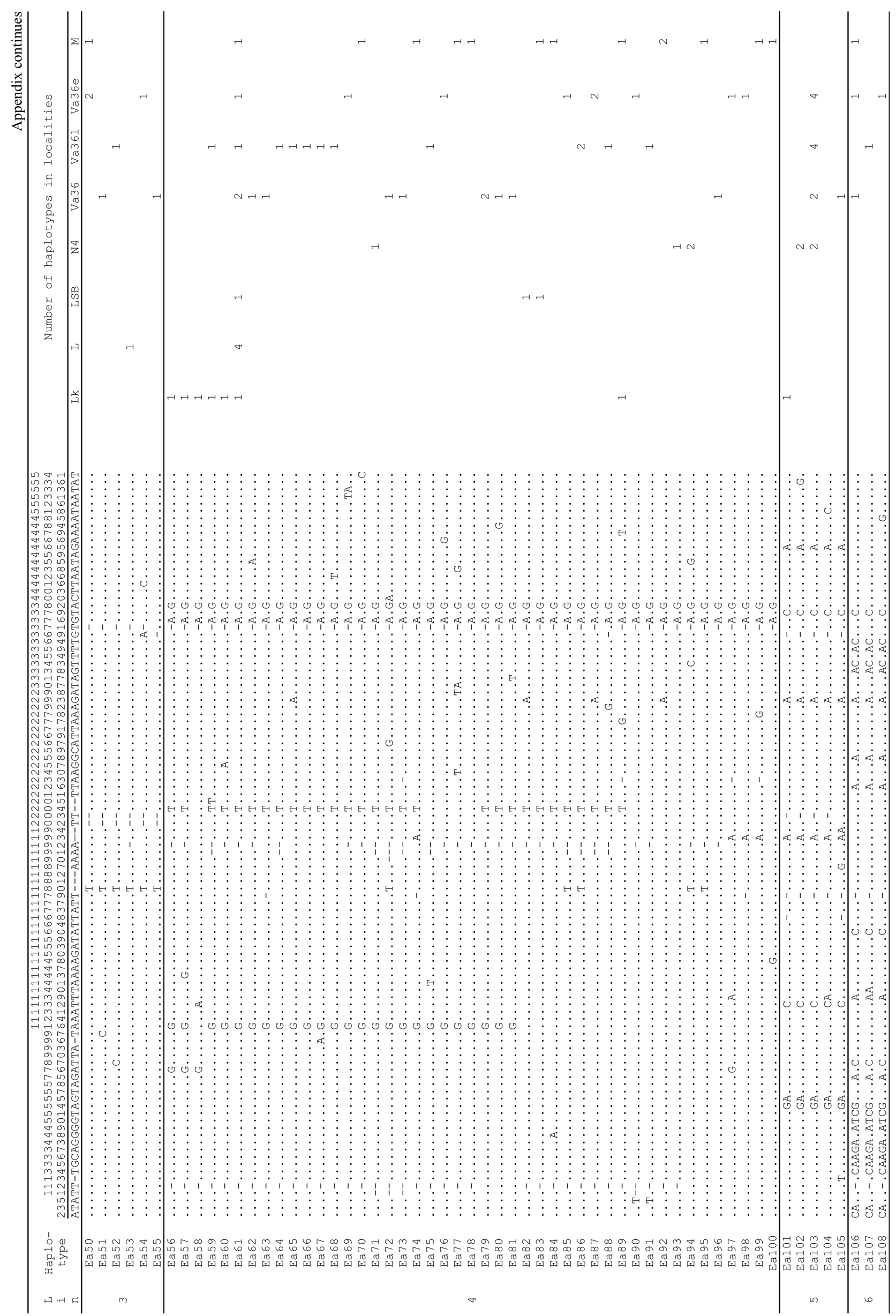

